\title{
Research on the revitalization of cultural prototype content industry
}

\author{
Kang Hur \\ Department of Cartoon\&Animation \\ Joong bu University, Geumsan-gun, Chungnam, Korea
}

\begin{abstract}
Korean Cultural Content Industry is developing creative cultural content based on internationally acknowledged manufacturing capacity, however, in order to become cultural industry with international competitiveness, it has to be planned and made in OMSU way. This research studied and analyzed successful cases of cultural content digital restoration and excellent cases of OSMU-type that has been developed and supported by Korean Culture and Contents Agency.

This study suggests the direction of growth on the basis of movement of cultural content industry and cultivating plan of human resources.
\end{abstract}

Keywords: Cultural prototype, OSMU(One Source Multi Use), Digital restoration, Cultural Contents Industry

\section{INTRODUCTION}

The movie, "A man of King", has created a 3-D graphics set to form beautiful images on film, but even more genuine than a real one, by using 'the Development of the contents in the digital life through the restoration of Han-Yang, the capital in the latter part of the Joseon Dynasty period,' which is one of the cultural prototype contents industry. This is a good example that has created a perfect movie with low-price and made the movie successful, achieving a higher value-added cultural business. Recently, with the development on digital technology, creative activities of culture contents have become a strong basis, influencing the global competitiveness. Now it is time for us to take a serious consideration on one's ability to produce cultural content and his or her creativity. In fact, in these days, when we look at cultural content that are nationally competitive, we can easily find numerous cases, which have succeeded in reprocessing myths and tales of various countries, such as animation, cartoon, and movies with the differentiated subject matter and initiative planning. Lately, cultural content industry is continually developing creative cultural content based on its manufacturing capability, acknowledged worldwide. However, in order to achieve cultural industry with the global competitiveness, how should we plan and manufacture? Answering this question is the purpose of this research.

Modern society is an age of cultural content where knowledge and creativity are emphasized. Having human's emotions, imagination, and creativity as a new power for the economic growth, the environment of people's lives has changed and digital conversion has evolved into ubiquitous, due to the combination of culture and technology. Anthropology,

\footnotetext{
*Corresponding author.E-mail : khur@joongbu.ac.kr Manuscript received Sep. 14, 2009 ; accepted Apr. 28, 2010
}

engineering, and art have their own purposes and different ways of approaching, and as they are combined together, the boundary is disappearing. In the era of the alteration and the amalgamation, we will define the notion of cultural content industry, and suggest the developmental direction for cultural content industry and the way to educate people. Based on cultural prototype of korean history and tradition, we analyzed a case for the development of 'One Source Multi Use' type cultural content and studied the developmental process in order to cultivate cultural content, so that through the digital restoration cases, World Cultural Heritages can be put for practical use in a variety of fields.

\section{CONCEPT AND CASES OF CULTURAL PROTOTYPE ON THE DEVELOPMENT OF THE CONTENTS}

\subsection{Cultural Prototype in Content Industry of Korea}

Changing the way of thinking about culture, we have established and been promoting a 5-year culture promotion plan to develop an essential and industrial strategy for the global competitiveness. For the promotion and development of the culture products, we established the culture and content agency, so that the contents of fine art, literature, and culture study can be used as a subject matter with different themes. We have been preparing a long-term development of cultural content industry through the accelerated distribution of contents, and also systemized the plan, so that it can be utilized and promoted industrially, improving the competition of cultural content industry.

Culture prototype demonstrates one nation's tradition and culture, and at the same time, it shows the existence of an element, which implies a global dimension of universality. 
Setting cultural prototype as a subject matter, we retest its contents and give the meaning with digital technology, so that it can be transformed into various medias, embodying valueadded.

Subject matter can be found in fine art and the humanities, and creative material development is significant for the successful cultural content industry. Creative subject matter is contents that should be available for the secondary application and it can be used diversely through unconstrained combination and disassembly.

Main field of the development focuses on our own imaginative story, such as a myth, legend, folk tale, history, and literature. A painting, calligraphy, dress and ornament, pattern, music, and dance can be the examples of artistic subject. There are also strategic subjects such as a battle, play, diplomacy, and trade as a form of life that is changing dynamically, and technological subjects such as architect, map, farming, fishing, cooking, and medical science.

Culture prototype industry makes a cultural heritage utilizable for its business field, therefore, not only we have to preserve a cultural heritage, but also we have to try to transform it into cultural content based on planning and manufacturing in culture industry. Successful cultural content can create a derived product market besides sales itself, and in addition to economic value, cultural content helps to overcome prejudice that traditional culture or a cultural heritage is antiquated and banal, and arouses public interest

\subsection{Cases of the Korean Cultural Prototype and the Development of the Contents}

\section{2. 1 OSMU (One Source Multi Use) type development}

By developing one content, we will expand it to various ways such as a movie, game, animation, fancy goods, broadcast, and publication, maximizing value-added. This means the role of multi use, following the demand and the need of a customer, and manufacturing and reconstructing the content by commercializing it diversely [1].

1) Digital restoration for traditional clothing and its cultural prototype in the Goryeo Dynasty period through the development of the design and 3-D manufacturing

\section{(1) Developing Outline and Its Contents}

By integrating data from clothing of the Goryeo Dynasty period, we will produce total 82 prototypes of clothes in 3-D graphics such as an official uniform, clothing for a gentry, a child, a maid of the court, the queen and the royal concubine of the Royal House, commoners, and musicians those who played the instruments or danced when a feast of the court or a parade outside of the royal palace was held. Therefore, we will be able to fulfill the demand of cultural content corporations and introduce beautiful fashion culture of Goryeo to the world.

\section{(2) Application Method}

Providing visual and auditory data from cyber museum of Goryeo clothing to institutions and fashion companies can be utilized for promoting publications about clothing and design. Also the data can be applied to character design for a movie, folk tale, and game, and to production for animation, public performance, and a play or drama. Figure 1 shows development of fashion culture of Goryeo by the Dream Hans [2].

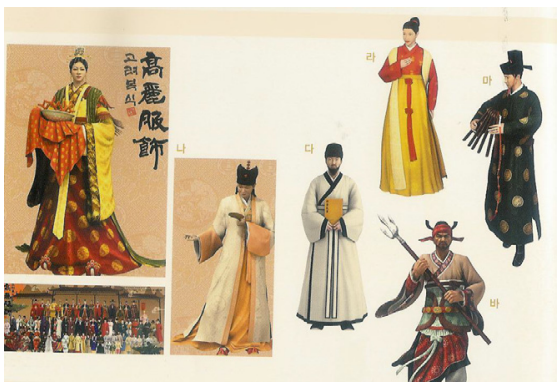

Fig. 1. Development of fashion culture of Goryeo,

\section{2) Development of Cyber Traditional Han-Ok Maeul Set (1) Developing Outline and Its Contents}

Background is the key element of image-type cultural content and architecture is an important part of the background. Beautiful architecture, Han-Ok, will be developed in digital graphics so that varied corporations of cultural content can use it. Based on the report of repairing a cultural treasure, photographs, and surveyed report on 160 different kinds of the architectures, considered as a national treasure in the Joseon Dynasty period, we have created 3-D virtual-reality image set.

\section{(2) Application Method}

Based on the surveyed information, architectural structures and space function of Han-Ok will provide practical resources and arrangement for the space, and it can be applied as design for theatrical art and a broadcast set, and as background for a game, movie, and drama. Figure 2 shows traditional Han-Ok maeul set development by the Yeogeum [3].

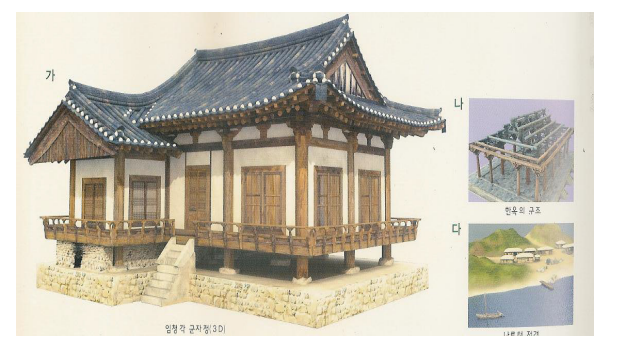

Fig. 2. Traditional Han-Ok Maeul set development,

3) Digital restoration on the prototypes of a merchant marine ship and a naval battle from prehistory to the Joseon Dynasty Period

Through digital technology, we are able to meet everything on tradition and culture of Korean merchant marine, which had the highly developed culture of marine commerce and technology from the ancient period, such as a korean traditional ship, naval forces, vessels, and even weapons from japanese invasion of Korea in 1592. By producing the ship of the Joseon Dynasty period (Pan-Ok-Seon), the ship of the Goryeo Dynasty period (Nu-Jeon-Seon), the ship of the Unified Silla period (GyoGwan-Seon), the naval battle of japanese invasion of Korea in 1592, korean traditional weapons (Cheon-Ja Chong-Tong, Joong-Wan-Goo), and more in 3-D graphics, we will use them as materials for a broadcast image, a toy model, and a vessel manufacturing in various culture industry. Figure 3 shows traditional merchant marine digital restoration development by the Korea Visual [4]. 


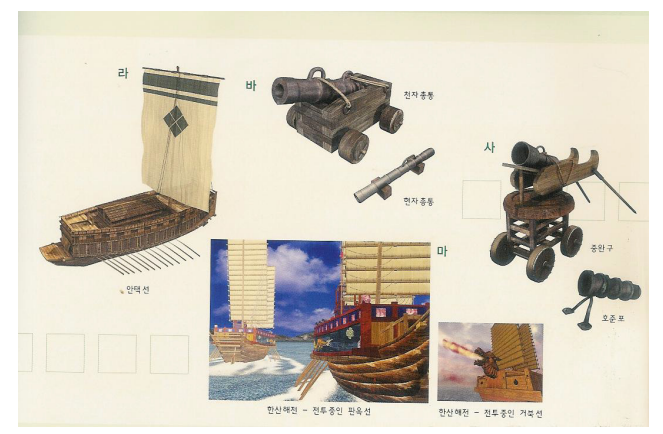

Fig. 3. Traditional merchant marine digital restoration,

\subsubsection{Cases of digital restoration of cultural heritage 1) Restoration of the Afghan Bamiyan Buddhas (1) Importance of the Bamiyan Buddhas}

The Bamiyan Buddhas, a full size stone Buddha with the size of $53 \mathrm{~m}$ by $38 \mathrm{~m}$, is the highest statue of the Buddha in the world that was built from the 2 nd century until the 5 th century in the culmination of Gandhara Buddhist Art, and it displays the influence of Hellenism. During the 6th and 7th century when Buddhism was in full flourish in Afghan, it is believed that Buddhist monks from all over the world swarmed to hear a mystic sermon, echoing in the rock [5]. The statue of the Buddha is a masterpiece and the greatest sculpture of Gandhara Buddhist image, expressed in a synthesis of Greco-Roman style, Persian style, and Western style based on Buddhism style in India. Its style went through China and influenced on a rock cliff Buddha in Gyeongju, Korea. In between the 4th and 5th century, Bamiyan took an important position of commerce and was the center of Buddhism, however, its face was destroyed by the Islam's invasion in the 8th century, arms and legs were cut out by Genghis Khan's Mongolian army in the 13th century, and 800 years later, it is utterly destroyed by the Taliban government in Afghanistan.

\section{(2) Restoration of Bamiyan stone Buddha}

Right after the destruction of the stone Buddha, it took one year to collect data, and digital restoration of Bamiyan stone Buddha got down to its job in 2002. Gumamoto Syoshin, who is a professor from Tokyo University in Japan, created a surveyed drawing and his data was used for the digital restoration. The result of restoring the stone Buddha's feet and legs, which had been cut out, was successful. Restoring the destroyed face was the most difficult problem; however, it was completed by inference, based on the research of European art historians. The most significant thing about the restoration of Bamiyan stone Buddha is being able to bring back the original form of the time in the 4 th and 5 th century. Figure 4 shows Bamiyan stone Buddha restoration [6].

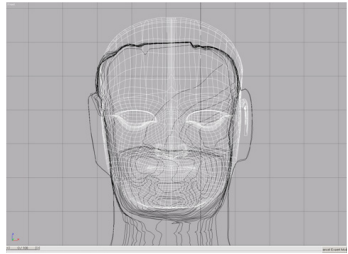

Fig. 4. Bamiyan stone Buddha restoration

\section{2) Digital Angkor Wat \\ (1) Characteristics of Angkor Wat}

Angkor Wat is a temple that was built in the beginning of the 12th century by the Khmer empire in the Angkor Dynasty, and Angkor means kingdom and Wat means rampart. There was a custom of building a shrine, because Khmer believed when a king or a royal family dies; one becomes equal to a god. It is a grand Hindu temple and a creation of King Surya Varman II, who achieved the heyday of the Angkor Dynasty. He built the temple in order to consolidate Vishnu, one of the major Hindu gods. Even though the architectural style of this temple was influenced by India, the building form and the decoration on the stone structure show Angkor's unique techniques. There are numerous Buddhist art pieces such as murals and sculptures that the whole temple is an aggregate of Buddhist art.

(2) The Development of the Contents in the meaning of

\section{Angkor Wat}

A historic site in Cambodia, Angkor Wat, is superior to an ancient Greek temple and Rome's ancient Coliseum in its artistry and magnificence. The restoration of Angkor Wat in 3$\mathrm{D}$ graphics has been tried, and what means the most is that digital restoration through worldwide CT technology of Korea and producing Angkor Wat as contents in a digital form were possible. Restoration by way of analog method is important, however, digital restoration can be put to practical use, which is much more excellent in cost and commercial utility. Figure 5 shows Angkor Wat 3D digital graphic [6].

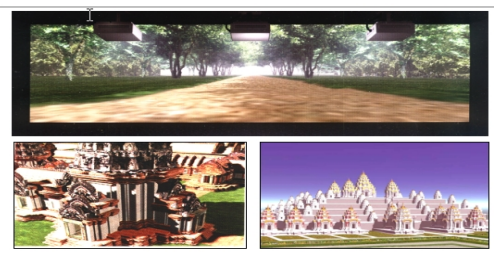

Fig. 5. Angkor Wat 3D digital graphic

\section{3) Restoration of Baekje Miruksa Temple Site}

Mireuksa is a place where the hope of King $\mathrm{Mu}$, who dreamed of the revival of Baekje, is dwelled, but only the fallen stone pagoda remains at the desolate temple site today. The scale of Mireuksa is 172 meters from east to west and 148 meters from south to north. Mireuksa is a massive temple that shows splendid engineering skills of Baekje people. The top of the stone pagoda of Mireuksa temple site is crumbled, and now only 6 stories are left. Cement is supporting the back part of the stone pagoda of Mireuksa temple site in order to prevent the falling during the Japanese occupation in 1915, and this has caused destruction of the other cultural assets [7].

Digital restoration of Mireuksa temple site is completed by field investigation through extensive data and research on Beopryungsa in Nara and Sachunwangsa Temple in Osaka, both in Japan, which were built by Baekje people in the same period. Figure 6 shows Baekje Mireuksaji 3D Restoration [8]. 

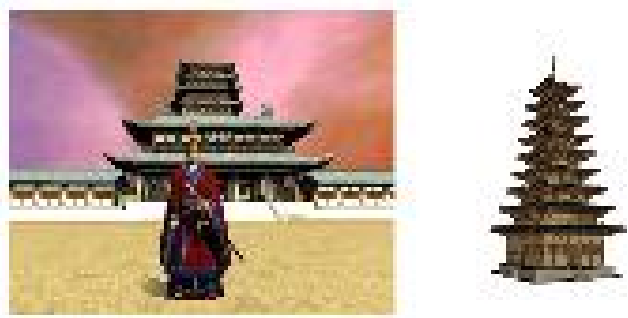

Fig. 6. Baekje Mireuksaji 3D Restoration

\section{4) Digital restoration of Seokguram}

\section{(1) Artistic Value of Seokguram}

Seokguram is Korean National Treasure No. 24 and a masterpiece that represents the formative art in the Unified Silla Dynasty period, which is also classified as national treasure in UNESCO. The structure of Seokguram consists of an antechamber and a main room. A rectangular antechamber has a statue of Deva King and after passing the corridor, where the four Devas are standing; there is a main room, which has the identical architecture of domed ceiling of Rome's Pantheon. The seated Buddha is located in the center of the main room, and the Bodhisattva of truth, the Bodhisattva of wisdom, and Buddha's 10 disciples are carved on the wall of the main room. As walking into the main room in Seokguram, magnificent and generous appearance of the principal icon of Buddha with the height of 350 centimeters is sitting towards East Sea in the middle of the round space which symbolizes heavenly bodies. The principal icon of Buddha's face, chest, shoulder, and knee in Seokguram are in the ratio of 1:2:3:4 and it has created an aesthetic element with a splendid geometric structure. When Seokguram was built, cultural exchange between East and West through Silk Road was very active. Seokguram is the masterpiece that has assimilated Eastern stone cave style and Western dome style in Korean style, and it is an international cultural heritage that architecture, mathematics, statistics, religion, and art are combined together on the whole [8].

\section{(2) Restoration to Cyberspace}

Digital restoration of Seokguram was created through 3-D scanning. Three-dimensional scanning is a method of reflecting laser to a sculpture, using the angle from projected laser and calculating the shape and the refraction of a solid into a data. It is used for the reproduction of delicate 3-D sculptures that cannot be represented in 3-D modeling. We save scanned data of Seokguram on the computer and use them after mapping the quality of the stone cave. With restored digital contents of Seokguram, the world biggest movie theater, exclusively for virtual reality, was built and the culture of the Silla Dynasty was restored and screened in Gyeongju World Culture Expo 2000. It was a project for neglecting time and space that we provided a stereophonic sound with 8 channels of surrounding volumes and 22 speakers for virtual reality, and also made people use their five senses to experience a scent of pine and acacia for the function of smell. Figure 7 shows Seokguram 3D graphic virtual reality [9].

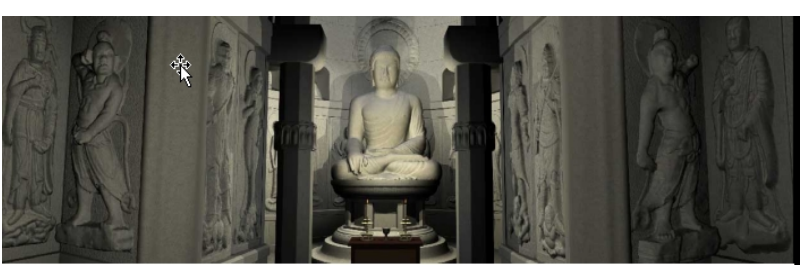

Fig. 7. Seokguram 3D graphic virtual reality

\section{CULTURAL CONTENT INDUSTRY}

\section{1 Cultural Content Trend}

Development in telecommunication has brought a remarkable change to our industrial society, and also to the ways of human lives. Even though the development of telecommunication started based on hardware, it was content which actually led to the progress. From now on, paradigms in industry will be changed from technology-based to human, culture, and naturalism-based, and contents and cultural industry, which has its basis on the contents, will be standing at the center of the change. In the 21 st century, a great transformation of paradigm has been processing in the world, from industrial society to knowledge driven economy where knowledge, emotion, creativity, and imagination of human are considered as a source for value-added. There has been a rapid change from manufacturing and service centered industrial production to various and comprehensive cultural production which merchandises cultural experiences. As the advent of ubiquitous environment approaches, all the countries in the world are acknowledging the growth of entertainment industry as a national and historical project, and promoting it as national strategic industry at the same time. It is predicted that the speedy growth of digital-based global entertainment industry market will be maintained and internet advertising and access market, and video game market will show the high rate of growth by $17.1 \%$ and $16.5 \%$ on each until 2009 . The environment of global cultural content industry is changing rapidly because of the acceleration of digital conversions. Especially, the key foundation structure, which will incorporate digital contents such as incorporation of broadcasting and communication (DMB, Digital Multimedia Broadcasting), consolidation of wire and wireless (mobile/ internet contents), and complex of a terminal (combination, combo, camcorder, camera), is changing.

\section{2 Prospect of Cultural Content Industry}

Global cultural industry has made about twelve hundred and thirty million dollars in 2003 and it is prospected to make about sixteen hundred and seventy million dollars in 2008 with $63 \%$ of the average annual growth rate. During the same time, annual growth of GDP is $5.7 \%$, showing that the development of cultural content industry has achieved a rapid growth rate compared to other industries. If we look into each different field in global cultural content industry, TV/broadcasting field and publishing field take the biggest part. The outlook of TV/broadcasting field is prospected to reach a relatively highgrowth until 2008, because of the diversification of a circulation channel such as common usage of DMB and 
expansion of multimedia service. On the other side, the outlook of publishing field is prospected to display $3.6 \%$ of the small growth rate because of the stagnation in the offline media industry [10].

Table 1. The scale of market and prospect of Cultural Content

\begin{tabular}{|c|c|c|c|c|c|}
\hline section & 2004 & 2005 & 2006 & 200 & 2008 \\
\hline game & 39,392 & 43,153 & 51,677 & 61,029 & 68,642 \\
\hline digital image & 99,180 & 120,607 & 141,308 & 163,599 & 187,912 \\
\hline $\begin{array}{l}\text { on-line } \\
\text { music }\end{array}$ & 4,141 & 6,748 & 10,379 & 15,159 & 20,219 \\
\hline e-learning & 6,431 & 8,080 & 10,250 & 12,662 & 15,821 \\
\hline $\begin{array}{l}\text { Web- } \\
\text { information } \\
\text { contents }\end{array}$ & 36,509 & 38,629 & 41,579 & 44,869 & 48,679 \\
\hline movie & 84,195 & 90,609 & 97,162 & 104,094 & 111,661 \\
\hline $\begin{array}{l}\text { TV/ } \\
\text { broadcasting }\end{array}$ & 161,414 & 174,987 & 187,964 & 200,313 & 213,465 \\
\hline
\end{tabular}

Internet advertising and access market and video game market will maintain the high economic growth until 2008, with the rate of $16.8 \%$ and $20.1 \%$ for each. In 2008 , video game market will surpass the music industry, and internet advertising and access market will surpass the newspaper market.

\subsection{Method of Human Resource Training in the Age of Cultural Content Industry}

The standard of the occupancy rate in the cultural content industry's global market is based on developed countries, and can deduce the current aspect towards policy implication for human resource training. The United States promotes independent investment and nurture of companies and private institute of education, rather than that of the nation-oriented, and the nation only performs indirect support like the law and the regime. England conveys the government's direct authority of supporting culture and art to an executive institute and various Fund culture in a relation to training human resources is revitalized. They are carrying out the fund rising in order to induce the participation of the corporation council. The government of Canada promotes human resource training directly and leadingly for the preservation of its own cultural industry and the enhancement for manpower competitiveness. Japan takes charge of functional support in cultural content industry for agency for cultural affairs under ministry of education, and private institute of education and companies are in charge of promoting manufactured human resources, and the government works directly on the cultivation of core leaders such as a producer and a director. Following a current aspect of policy implication, a model of human resource training, led by the government (Australia and Canada), is needed during the growth period, and a dualistic model of human resource training, focusing on the function of manpower like Japan does, has to be done simultaneously. Promotion of human resource training driven by private (the United States) is appropriate for the maturity period. In order to increase the participation of human resource training, the method of fund raising for cultivating manpower (England) has adopted.

Table2. Major Institution and Regime on Human Resource Training in Overseas. Provided by Agency [11]

\begin{tabular}{|c|c|c|c|c|c|}
\hline sectin & $\begin{array}{l}\text { Name of } \\
\text { instituti } \\
\text { on }\end{array}$ & $\begin{array}{l}\text { Purpose of } \\
\text { administra } \\
\text { tion }\end{array}$ & $\begin{array}{c}\text { Training } \\
\text { Form }\end{array}$ & $\begin{array}{c}\text { Training } \\
\text { period }\end{array}$ & $\begin{array}{c}\text { Applicatin } \\
\text { Form }\end{array}$ \\
\hline \multirow{3}{*}{$\begin{array}{l}\text { governm } \\
\text { ent } \\
\text { driven }\end{array}$} & $\begin{array}{l}\text { CHRC } \\
\text { (Canada }\end{array}$ & $\begin{array}{c}\text { Cultural } \\
\text { manpower } \\
\text { Recruiting/ } \\
\text { network }\end{array}$ & $\begin{array}{l}\text { requisition/professi } \\
\text { onal network } \\
\text { / career } \\
\text { development } \\
\text { /internship }\end{array}$ & always & $\begin{array}{c}\text { On/off network } \\
\text { service }\end{array}$ \\
\hline & $\begin{array}{l}\text { Cheve } \\
\text { ning } \\
\text { (England) }\end{array}$ & $\begin{array}{l}\text { Inducement of } \\
\text { excellent } \\
\text { foreign students }\end{array}$ & $\begin{array}{l}\text { Support } \\
\text { scholarship for } \\
\text { college } \\
\text { students }\end{array}$ & $\begin{array}{l}\text { Degree } \\
\text { period }\end{array}$ & $\begin{array}{l}\text { Tuition, allowance, and } \\
\text { living expenses are } \\
\text { provided. } \\
\text { Premium allowance } \\
\text { provided }\end{array}$ \\
\hline & $\begin{array}{l}\text { DCAI } \\
\text { (Japan }\end{array}$ & $\begin{array}{l}\text { Digital contents } \\
\text { manpower } \\
\text { overall support }\end{array}$ & $\begin{array}{c}\text { Classified by } \\
\text { project }\end{array}$ & $\begin{array}{c}\text { Classifie } \\
\text { d by } \\
\text { project }\end{array}$ & $\begin{array}{c}\text { Classified by } \\
\text { project for } \\
\text { payment }\end{array}$ \\
\hline \multirow{2}{*}{$\begin{array}{l}\text { Privae } \\
\text { driven }\end{array}$} & $\begin{array}{c}\text { AFI } \\
\text { (U.S.A) }\end{array}$ & $\begin{array}{c}\text { Movie } \\
\text { manpower } \\
\text { education }\end{array}$ & $\begin{array}{l}\text { collaboration } \\
\text { project } \\
\text { execution and } \\
\text { coaching }\end{array}$ & $2 \mathrm{yrs}$ & $\begin{array}{l}34 \text { kinds of } \\
\text { scholarship system } \\
\text { managemnt }\end{array}$ \\
\hline & $\begin{array}{c}\text { Skill } \\
\text { set } \\
\text { (England) }\end{array}$ & $\begin{array}{l}\text { audio-visual } \\
\text { industry } \\
\text { manpower } \\
\text { cultivation }\end{array}$ & $\begin{array}{c}\text { Short-tem } \\
\text { curriculum } \\
\text { (public/custom- } \\
\text { made) }\end{array}$ & $1 \mathrm{yrs}$ & $\begin{array}{l}\text { Education fee } \\
\text { provided } \\
\text { Educational } \\
\text { institution }\end{array}$ \\
\hline $\begin{array}{l}\text { Privae } \\
\text { driven }\end{array}$ & $\begin{array}{l}\text { UCLA } \\
\text { ET } \\
\text { (U.S.A) }\end{array}$ & $\begin{array}{c}\text { Media } \\
\text { manpower } \\
\text { cultivation }\end{array}$ & $\begin{array}{c}\text { Short-tem } \\
\text { curriculum/ } \\
\text { completion course } \\
\text { On-line education// } \\
\text { enterpriseducation }\end{array}$ & $\begin{array}{c}2 \mathrm{yrs}- \\
1 \mathrm{yr}\end{array}$ & \\
\hline
\end{tabular}

For the development of cultural content industry, we need a hard-core of manpower with one's ability that can bring a strong effect on cultural content industry and one who has a comprehensive judgment in business, art, and technology, and has a professional capacity on each field.(industry leader, business leader, creative leader-contents director, technology leader). Fieldwork professionals should be able to plan, create, develop, manufacture, circulate, and manage, and the cultivation of industry fieldwork professionals, who are able to accomplish each particular steps expertly, is necessary.

Table3. Manpower Structure of Cultural Content Industry

\begin{tabular}{|c|c|c|c|c|c|c|}
\hline \multirow{2}{*}{$\begin{array}{l}\text { section } \\
\text { Fieldwok } \\
\text { professio } \\
\text { nals }\end{array}$} & \multicolumn{6}{|c|}{$\begin{array}{l}\text { industry leader(business leader) } \\
\text { technology leader }\end{array}$} \\
\hline & $\begin{array}{l}\text { planni } \\
\text { ng }\end{array}$ & creation & $\begin{array}{l}\text { develop } \\
\text { ment }\end{array}$ & $\begin{array}{l}\text { manufac } \\
\text { turing }\end{array}$ & $\begin{array}{l}\text { circulati } \\
\text { on }\end{array}$ & $\begin{array}{l}\text { Preservation, } \\
\text { management }\end{array}$ \\
\hline $\begin{array}{l}\text { Reserved } \\
\text { professio } \\
\text { nals }\end{array}$ & \multicolumn{3}{|c|}{$\begin{array}{l}\text { regular educational institution } \\
\text { undergraduates }\end{array}$} & \multicolumn{3}{|c|}{ Other field professionals } \\
\hline $\begin{array}{l}\text { Basic } \\
\text { potential } \\
\text { manpowr }\end{array}$ & \multicolumn{6}{|c|}{ School's core leader of educational institution undergraduates } \\
\hline $\begin{array}{l}\text { Infra } \\
\text { (infrastru } \\
\text { cture) }\end{array}$ & \multicolumn{2}{|c|}{$\begin{array}{l}\text { Public sector } \\
\text { (law, policy) }\end{array}$} & \multicolumn{2}{|c|}{$\begin{array}{l}\text { Manpower } \\
\text { information } \\
\text { (system) }\end{array}$} & \multicolumn{2}{|c|}{$\begin{array}{l}\text { qualification/certification } \\
\text { (regime) }\end{array}$} \\
\hline
\end{tabular}

In order to cultivate core leaders of cultural content industry, we need systematic cultivation and early establishment of the core leader, construction of manpower in global network, capability reinforcement in industrial manpower. Therefore, the efficiency on managing public institutions and cyber educational system has to be accomplished, and we also need to manage a proper program for the actual demand of industry and strengthen the capability of academic institutions by activating the industry-academic connection. 


\section{RESEARCH SUMMARY AND CONCLUSION}

In the future, we will be entering the ubiquitous era where IT Network becomes an everyday affair. It is also the 5 any (anytime, anywhere, anything, any network, any device) era. The development of communications has brought a great change in our lives and also a form of human lives. The development of communications started its foundation on hardware; however, it is a content that led to substantial development. Hereafter paradigm in industry will be changed from industry-based to human, culture, and Naturalism-based. Cultural industry and contents will be standing at the center of the change. The advent of Ubiquitous Environment in media has enlarged the advantages of using convenient media at home. Depending on life surroundings, accessing various contents has become possible, so that new business flow is forming, which decides the manufacture and the consumption of the contents by acknowledging the situation. In the ubiquitous era, contents that utilize network and media will be communized and it will be possible to use media as a consolidated Plat form, which conveys the contents, and the contents will become a core source that combines individual media and induces the growth of related market. Cultural content industry has become a highvalued cultural product under the concept of OSMU, with the strategy that various art works will be recreated through one successful original work. The advent of the interactive media along with the development of technology has been changing, following the need of individuals and a society, for example, easy access on using, utilization in a comfortable situation, choices on various programs, possibility of lapse into virtual reality, increment of possessiveness through the visualized form of delivered information, and extension of leisure time. This shows our cultural environment in the present day, and it suggests the method for the development of cultural content industry. Developed countries that are having a downturn of the competitiveness in manufacturing field, because of the higher wage, are betting their future on the cultural industry. Creating a movie, drama, and animation from using one content has become power of a growth industry for the new 21 st century. This modern society is the age of cultural content. Finding who secures more contents and makes them interesting is highly considered because the person can control one nation's future. Investment and exertion on developing on source for the creation in cultural contents, which can lead a trend of global culture, are significant matters in a reality where the leading power of the 21 st century industry is transforming into cultural contents. A movie, animation, game, and broadcasting image that have the creativity as the essential element, are the main sources for the creation of cultural contents, including comprehensive humanities and traditional art. These fields have to be acknowledged not simply as a creation of art, but as a field of culture and technology that leads productive power of cultural industry. We have to develop cultural content by actualizing originality and imagination in a field of the humanities, which is the foundation of cultural technology (CT), and by combining technology for the new program. However, the biggest problem in the present state is that the humanities, technology, and art are in a state of disorder, so that the cooperation is needed more. The outcome of cultural industry, cultural content, has its foundation on the humanities, like history, tradition, literature, imagination, and artistic creativity, and a field of technology is what embodies and actualizes cultural contents. Therefore, communication and fusion of the humanities, engineering, and art, are absolutely necessary and the interdisciplinary cooperation for successful cultural content should be searched.

Revitalization and development of the knowledge industry is influenced unconditionally by securing competitive human resources, and cultural content industry is not an exception. Various forms of formality and unofficial professional curriculums have to be set up in order to cope with a rapidly changing market flow and to fulfill the demands on education in the industrial fieldwork. Furthermore, we have to acknowledge the importance of assuring excellent human resources for the development of cultural content industry from aspect of a nation, and devise a method for high-tech human resource training, related to cultural content upon the national policy on the long-term development of human resource. As the keynote of the research, we examined and analyzed the trend and the development strategy in cultural content industry. And we studied the successful elements for culture content and examined the cases of development on a prototype of korean culture and the successful cases of digital restoration.

The role of cultural content industry is retesting material from the prototype of culture and embodying value-added by granting the meaning, so that the prototype of culture can be transformed into a diverse range of media through digital technology. Cultural content industry is in the spotlight as a high-speed growth industry for the global competitiveness that makes a higher value-added on materiality and immateriality.

The video, which used a prototype of Korean culture as a topic, has created the new wave of Korean culture not only in Asia, but also in America by introducing Korean tradition and culture. Cultural asset is the aggregate outcome, attained by human through knowledge, faith, art, and customs. It also shows the spirit of the era as evidence that we have to teach the continuity of the past and the future as a broad object and need to preserve it. Reproducing cultural assets, which no longer exists or has been destroyed, is a big challenge. Nonetheless, difficulties in the preservation and the restoration can be resolved through the digital restoration of cultural assets in virtual reality. As the problem, systematic result, such as history and archeology, has not been accumulated and participation of manpower is not specialized because of the unconfirmed theory.

Archeological and historical study is restored through the historical research from the possessions of certain scholars that the study can be used in an exhibition or a book for educational purpose. Digitalizing cultural assets will be revitalized more since people are living in a society where internet and satellite are well developed, and introducing culture and showing will make people feel comfortable. In the $21^{\text {st }}$ century, the humanities will be transformed and developed eventually through digital technology as a trend that works in perfect tune with the general public.

Cultural content is a core element for the potentiality and the global competitiveness that creates not only industrial value, but also social cultural value. Through the development of cultural content and its application, the interaction of 
interdisciplinary professionals will get more active and will accomplish amalgamative development. For cultural content industry to approach people friendly and directly, the prototype of culture has to be used as commercialized contents through popular channels such as a drama and movie.

\section{REFERENCES}

[1] E.K. Kwon, Korean Cultural Prototype-based OSMU-type Cultural Prototype Development Research, Yonsei University, 2006, pp.19

[2] Dream Hans, Korea culture content agency, KOCCA, 2003, pp.64-67.

[3] Yeogeum, Korea culture content agency, KOCCA, 2003, pp.168-171.

[4] Korea Visuals, Korea culture content agency, KOCCA, 2003, pp.176-179.

[5] S.Y. Kim, Research on Cultural Treasure Digital Revitalization, Dankook University, 2003, pp.57

[6] www.culturecontent.com.

[7] J.H. Park, Hwang Yong Temple, Dream of the World, Sumaksae, 2006, pp.56

[8] H.H. Lee, J.H. Park, Korean History Story, Chung-A Publishing Co., 2005

[9] J.H. Park, Hwang Yong Temple, Dream of the World, Sumaksae, 2006, pp.13

[10] Culture and Contents Agency, Cultural Content Industry Prospect, 2005, pp.38

[11] C.S. Choi and etc., Cultural Content Study Curriculum Guide Book, Korean Culture and Contents Agency, 2003, pp.65

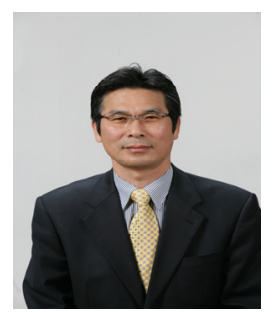

\section{Kang Hur}

Received his $\mathrm{Ph}$. D degrees from Moscow State University of Printing Arts in 2007.

He is currently a professor in Department of Cartoon \& Animation of Joongbu University. His research is on the Development of the Contents in the Method of Korean Buddhist Sculpture of young monk. His paper is Cultural Content 